\title{
Intravenous Thrombolytic Therapy in Acute Stroke: Frequent Systemic Problems and Solutions
}

\author{
Akut İnme Tedavisinde İntravenöz Trombolitik Tedavi: Sık Görülen Sistemik Sorunlar \\ ve Çözümleri
}

\author{
(1) Mehmet Akif Topçuoğlu1, (1) Ethem Murat Arsava1, (1) Atilla Özcan Özdemir², ( Erdem Gürkaş3, \\ (1) Dilek Necioğlu Örken ${ }^{4}$, (1) Şerefnur Öztürk 5 \\ ${ }^{1}$ Hacettepe University Faculty of Medicine, Department of Neurology, Ankara, Turkey \\ 2Eskisehir Osmangazi University Faculty of Medicine, Department of Neurology, Eskisehir, Turkey \\ 3Health Sciences University, Gulhane Training and Research Hospital, Clinic of Neurology, Ankara, Turkey \\ 4Istanbul Bilim University Faculty of Medicine, Department of Neurology, Istanbul, Turkey \\ 5 Selcuk University Faculty of Medicine, Department of Neurology, Konya, Turkey
}

\begin{abstract}
One of the most important reasons why the use of the intravenous (IV) tissue plasminogen activator (tPA), which is one of the key elements of acute ischemic stroke treatment, is not sufficiently widespread is the fact that many common questions have not been adequately answered. In this review, questions about systemic nonneurologic conditions, problems related with IV tPA treatment and complications of treatment, which were collected from our colleagues practicing in Turkey and which are more important in clinical practice, were answered on the basis of the current literature and clear recommendations are made.
\end{abstract}

Keywords: Stroke, thrombectomy, contraindication, avoidance, cerebral hemorrhage

$\ddot{O} \mathbf{z}$

Akut iskemik inme tedavisinin ana elementlerinin başında gelen intravenöz (IV) doku plazminojen aktivatörü (tPA) kullanımının yeterince yaygınlaşamamasının en önemli nedenlerinden biri sık karşılaşılan birçok soruya yeterince yanıt veril(e)memiş olmasıdır. Bu derlemede akut inmede IV tPA tedavisi ile ilgili olarak meslektaşlarımızdan toplanan, daha çok uygulamada önemi olan sistemik soru ve sorunlar ile tedavinin komplikasyonlarına dair, sorulara güncel literatür temelinde yanıt verilmiş ve net tavsiyelerde bulunulmuştur.

Anahtar Kelimeler: Strok, trombektomi, kontrendikasyon, kaçınma, serebral kanama

\section{Introduction}

One of the factors that play a role in the non-spread of the use of intravenous (IV) tissue plasminogen activator (tPA) in clinical practice of acute stroke is the question on how treatment will be applied in relatively common special conditions. In this, the second part of the review, systemic problems that can take place in clinical decision-making processes in systemic tPA applications and some tPA-related complications are discussed along with the current literature.
Question: Can IV thrombolytic therapy be applied in patients aged over 80 years?

Answer: Yes, treatment can be applied in patients aged over 80 years who do not meet the exclusion criteria for IV tPA use except age criterion. Despite the higher risk of symptomatic intracerebral hemorrhage (ICH) compared with younger age, the positive effect of the drug on clinical outcomes is not reduced by the use of IV tPA for acute ischemic stroke in older patients (1). Although the benefit/loss ratio is lower than in younger patients, IV tPA in the elderly is useful in the final analysis and should be

Address for Correspondence/Yazışma Adresi: Mehmet Akif Topçuoğlu MD, Hacettepe University Faculty of Medicine, Department of Neurology, Ankara, Turkey Phone: +90 5365753634 E-mail: mat@hacettepe.edu.tr ORCID ID: orcid.org/0000-0002-7267-1431

Received/Geliş Tarihi: 21.08.2017 Accepted/Kabul Tarihi: 13.11.2017

${ }^{\circ}$ Copyright 2018 by Turkish Neurological Society

Turkish Journal of Neurology published by Galenos Publishing House. 
applied. There is no age limit for IV tPA that is based on scientific evidence, it is applicable in all cases.

In the National Institute of Neurological Disorders and Stroke (NINDS) tPA trial and in the American Heart Association (AHA) guideline, IV tPA is indicated to be applicable to all adults aged 18 years and older and advanced age has not been considered as an exclusion ( $11 \%$ of cases in the NINDS trial were aged over 80 years) or contraindication criterion $(1,2,3)$. However, many prospects, including those in force in our country, have an upper age limit for application (4). For example, the statement "In elderly patients, Actilyse ${ }^{\circledR}$ should be used following careful evaluation in each individual patient. Actilyse ${ }^{\circledR}$ cannot be used for the treatment of acute stroke in patients over 80 years of age" is written in the instructions for use in Turkey. Considering the average life span and the mean age of patients who have a stroke in our country, age restriction can be predicted to lead to the deprivation of many patients from this beneficial treatment.

The source of this misconception can be said to be European Cooperative Acute Stroke Study III (ECASS-III) (5), as well as some observational studies and expert opinions. For example, in a metaanalysis of 3178 patients who were collected from a large number of observational studies, it was observed that the risk of death after tPA in the elderly (>80 years) increased 2.8 -fold compared with those younger than 80 years and that the favorable outcome rate decreased by $50 \%$. In this analysis, increased symptomatic $\mathrm{ICH}$ with increasing age did not reach significance level [Odds ratio $(\mathrm{OR})=1.31,95 \%$ confidence interval $(\mathrm{CI})$ : 0.93-1.84] (6). In addition, older age was found to be a risk factor for tPA-related hemorrhage in other studies and old age featured in almost all of the scales aiming at predicting the risk of bleeding after TPA (7). Contrary to this data, more observational and all randomized studies have shown findings that did not support an age limit.

In a combined analysis of 3472 patients over the age of 80 (around 12\%) included in the VISTA and SITS databases, the benefit of TPA in patients aged over 80 years (improved outcome OR 1.4) was found to be equivalent to those below age 80 (improved outcome OR 1.6) (8). Furthermore, in randomized controlled trials, tPA seems to be significantly more beneficial than placebo over the age of 80 years. One thousand six hundred seventeen older patients ( $>80$ years) included in the third International Stroke Trial (IST-3) accounted for $53 \%$ of the study population, and tPA responses of these patients were higher than in the younger patients within the first 3 hours (9). In a metaanalysis of 6756 patients from 9 randomized trials conducted by "The Stroke Thrombolysis Trialists' Collaborative Group" (STTCG), excellent outcome [modified Rankin score (mRS) 0 or 1] was reported in $17.6 \%$ of 879 patients aged over 80 years who received $\mathrm{tPA}$, whereas it remained at $13.2 \%$ in the control group ( 850 patients). That is, the probability of getting very good results with tPA in this age group has shown 1.56-fold increase. In the same study, this increase was 1.25 -fold in patients under the age of 80 . However, good outcome at younger ages is higher in both tPA (39.4\%) and control groups (33.9\%) than in older patients (10). The same situation is true for survival analysis. Although advanced age is inversely proportional to survival, the survival benefit with tPA is not age-dependent and is similar in the elderly (1).

\section{Question: How should IV tPA be performed in patients with high blood pressure?}

Answer: In the AHA guidelines, a systolic blood pressure (SBP) of over $185 \mathrm{mmHg}$ and/or diastolic blood pressure (DBP) of over $110 \mathrm{mmHg}$ during two pre-treatment measurements is a contraindication for the use of IV tPA in patients with acute ischemic stroke (3). The United States Food and Drug Administration (FDA), on the other hand, chose not to mention a level and preferred the expression "present severe, uncontrolled high blood pressure" (11). Similarly, there is a statement "severe uncontrolled high blood pressure" in the label for use of Actilyse ${ }^{\circledR}$ in our country (4). In addition, contraindications include "DBP over $110 \mathrm{mmHg}$ or the need for intensive treatment (with IV medication) to reduce the DBP to less than $110 \mathrm{mmHg}$." However, there is no expression for SBP (4). The blood pressure limit criterion is the most common (about 50\%) reason for not administering IV tPA in everyday life (1).

The high arrival/admission SBP or DBP was considered as a risk factor for post-tPA symptomatic hemorrhage in "Safe Implementation of Treatments in Stroke" (SITS) (12) and "Get With The Guidelines-Stroke" (GWTG) (13) in the large phase-4 patient series that were compiled after the market. Moreover, increased blood pressure is "directly proportional" to an increase in the risk of bleeding. To reduce or prevent this risk, it is recommended that the blood pressure be lowered below 185/110 $\mathrm{mmHg}$ before treatment and kept below 180/105 $\mathrm{mmHg}$ for 24 hours after treatment $(1,3,4)$.

Reduction of blood pressure within the treatment window of acute ischemic stroke can negatively affect the fate of the existing penumbral tissue on the basis of autoregulation failure. For this reason, the aggressive reduction of blood pressure is not recommended except for some special cases. One of the early posthoc analyses of the NINDS study has addressed this issue and noted that every $10 \mathrm{mmHg}$ reduction in SBP negatively impacted functional outcome at discharge. In particular, reductions of more than $50 \mathrm{mmHg}$ have been shown to cause significant deterioration and mortality (14). In the NINDS trial, high SBP was $19 \%$ before treatment $(>185 \mathrm{mmHg})$ and $60 \%$ after treatment $(>180$ $\mathrm{mmHg}$ ). An anti-hypertensive was used in $9 \%$ of patients during pre-randomization and in $24 \%$ after randomization. The high blood pressure after treatment also negatively affected the results of the non-bleeding cases at the $3^{\text {rd }}$ month (15).

IV tPA can be administered if SBP $<185$ and $\mathrm{DBP}<110 \mathrm{mmHg}$ in acute stroke. There is no need for additional interference, close follow-up is enough. The pre-existing hypertension, its duration and level of control are important when a patient is assigned a specific blood pressure limit. For this purpose, the detection of the effects of chronic hypertension such as hypertensive retinopathy, left ventricular hypertrophy, and cerebral hypertensive white matter lesions in the patient may suggest that the range of autoregulation values is shifting higher.

If SBP is between $185-220 \mathrm{mmHg}$ and DBP is between 110-120 $\mathrm{mmHg}$, the blood pressure level should be adjusted to the desired range pharmacologically before IV tPA. For this purpose, metoprolol and nitroderm $\operatorname{TTS}^{\circledR}(5$ and $10 \mathrm{mg}$ ) may be administered first, and IV tPA can be administered if it decreases to the desired range. Metoprolol is marketed under 
the name Beloc ${ }^{\circledR}$ and the ampoules are $5 \mathrm{mg}$. Its effect starts in $5-10$ minutes and lasts $2-4$ hours; 2.5 or $5 \mathrm{mg}$ boluses may be given in 5 to 15 minutes intervals. The dose of $15 \mathrm{mg}$ should not be exceeded in stroke. In these values, 'aggressive' blood pressure control with continuous IV infusion (such as nimodipine, nitroglycerin, furosemide or nitroprusside) is risky and is generally not recommended. However, esmolol is quite suitable in refractory cases because it has a very short duration of effect. The common market name for esmolol is Brevibloc ${ }^{\circledR}$, which has two forms: a vial $(10 \mathrm{mg})$ and a Premix ${ }^{\circledR} \mathrm{bag}(10 \mathrm{mg} / \mathrm{mL}-250 \mathrm{~mL})$. Its effect starts in 1-5 minutes and lasts 10-20 minutes. It is started with bolus (250-500 $\mu \mathrm{g} / \mathrm{kg}, 1-3$ minutes) and is maintained with infusion (50-300 $\mu \mathrm{g} / \mathrm{kg} / \mathrm{minutes})$ under close follow-up. The infusion is titrated upwards with a 4 -minute increase of $50 \mu \mathrm{g} / \mathrm{kg} /$ minute and a bolus dose of $50 \mu \mathrm{g} / \mathrm{kg}$ is repeated if necessary. Blood pressure is usually lowered to the desired level with esmolol.

If the SBP is $>220 \mathrm{mmHg}$ or the DBP $>120 \mathrm{mmHg}$ in acute stroke, it is suggested to reduce it in a controlled manner. Sodiumnitroprusside is preferred if blood pressure does not decrease with the above measures or if there are esmolol contraindications such as bradycardia. The market name is Nipruss ${ }^{\circledR}$, which is found as a 5 cc $60 \mathrm{mg}$ vial. Sixty milligrams of sodium nitroprusside is dissolved in $3 \mathrm{~mL}$ of sodium citrate and then drawn into a $50 \mathrm{~mL}$ perfusion syringe. It is then filled up to $50 \mathrm{~mL}$ with $5 \%$ dextrose (only) and administered with $1 \mathrm{~mL} / \mathrm{h}$ infusion. It must be protected from light by wrapping with aluminum foil. The effect may start immediately and may be evident at an unpredictable level; therefore, radial invasive blood pressure follow-up is required. The dosage is increased until the blood pressure reaches the desired range, and the maximum infusion rate is $10 \mu \mathrm{g} / \mathrm{kg} / \mathrm{min}$. There is a risk of cyanide toxicity if exceeding $2 \mu \mathrm{g} / \mathrm{kg} / \mathrm{min}$ or $0.5 \mathrm{mg} / \mathrm{kg} /$ $\mathrm{hr}$. There is also the risk of developing cerebral steal phenomenon.

ACE inhibitors, including sublingual captopril or lisinopril, are generally not recommended before thrombolytic therapy because they increase the risk of orolingual angioneurotic edema after IV tPA (approximately 5\%).

The follow-up of vital signs and neurologic examinations are essential in neuro-intensive care units after thrombolytic therapy. Blood pressure, body temperature, pulse, and respiration rate are measured every 15 minutes for the first two hours, then every 30 minutes for up to the sixth hour, and once an hour for the remaining period. The increased blood pressure is highly critical because it varies in this period according to the changes in the clinical situation and whether there is recanalization. Regarding two or more measurements taken at ten-minute intervals, esmolol in case of an SBP of 180-230 mmHg or a DBP of 105-120 mmHg, esmolol or sodium nitroprusside in case of an SBP $>230 \mathrm{mmHg}$ or a DBP of 121-140 $\mathrm{mmHg}$, and sodium nitroprusside in case of a DBP $>140 \mathrm{mmHg}$ should be administered at 'standard' doses to control blood pressure. If continuous arterial blood pressure monitoring is required during IV nitroprusside infusion, the risk of bleeding due to arterial catheterization should be assessed in a comparative way with the risk of a dramatic blood pressure change during infusion.

Question: How should blood glucose IV be managed in patients with stroke who are tPA candidates?
Answer: When planning a treatment in a patient with acute ischemic stroke, the blood glucose level should be known. For the safe use of IV tPA, substituting from the NINDS tPA trial, the AHA stated that blood glucose should be between $50-400 \mathrm{mg} /$ $\mathrm{dL}$ (3). However, later, the upper limit was removed and then IV tPA was stated to be only contraindicated for patients with hypoglycemia (blood glucose $<50 \mathrm{mg} / \mathrm{dL}$ ). One of the leading reasons for this is that hypoglycemia and hyperglycemia can potentially lead to focal symptoms, meaning that stroke diagnosis cannot be known for certain in cases of such impaired glycemia. However, the distinction can be clearly made by showing clinical improvement parallel to glycemic control or by showing occlusion in vascular imaging. Also, the main differences in the clinical status are guiding. So the distinction can often be achieved.

Therefore, IV tPA is recommended in the presence of extreme glycemia values in the last period. Thus, there is no blood glucose value to make tPA application useless. On the other hand, it is not common for blood glucose to be out of the range of $50-400 \mathrm{mg} /$ $\mathrm{dL}$ before giving tPA, and it is found in less than $1 \%$ of patients.

However, hyperglycemia is a condition that must be detected and meticulously treated in patients with stroke because hyperglycemia has an effect on reducing favorable outcomes, accelerating penumbral loss, decreasing the chances of successful reperfusion, and increasing bleeding risk $(16,17,18)$. In a metaanalysis, it was found that a $1 \mathrm{mmol} / \mathrm{L}$ (approx. $18 \mathrm{mg} / \mathrm{dL}$ ) increase in admission glucose level was associated with an $8 \%$ decrease in favorable outcomes and a $9 \%$ increase in symptomatic intracranial hemorrhage (16). The risk of bleeding was increased 5.9-fold in patients with abnormal blood glucose levels ( $>400$ in 14 patients and $<50$ in 1 patient) in the SITS-EAST database $(n=5461)$ and the likelihood of favorable outcomes decreased by $8.6 \%$. However, this negative picture was not seen in every study. For example, in the VISTA database $(n=9613)$, there was no increased risk of hemorrhage in 6 patients with blood glucose $>400 \mathrm{mg} / \mathrm{dL}$ and 5 patients with $<50 \mathrm{mg} / \mathrm{dL}$ (19). On the other hand, although a high admission glucose level is an important risk, higher and uncontrolled values during follow-up are more important risks (20). The blood glucose level should be controlled throughout the entire course of acute stroke. However, this approach does not change for patients who are receiving and will receive thrombolytic therapy.

\section{Question: Is diabetic retinopathy contraindication for IV tPA?}

Answer: In patients with acute myocardial infarction (AMI) and acute stroke, ocular hemorrhage has been reported, although very rarely, in various forms after IV tPA (21). Despite this very low risk, the FDA has also placed a warning label for use in "hemorrhagic" diabetic retinopathy and other hemorrhagic retinopathies, taking into account the 'old' warning for the use of tPA in AMI $(11,22)$. However, there is no such warning in the current AHA stroke guide (3). The risk of retinal hemorrhage in patients with diabetes receiving high-dose IV tPA in combination with heparin and aspirin in AMI has been determined as $0.05 \%$, and this risk was stated not be an obstacle to the use of IV tPA in AMI (23). Therefore, it can be predicted that the risk is much lower and does not constitute a contraindication in patients with 
stroke who have this drug alone and in lower doses (24). There are no statements on this issue in the instructions for use in our country (4).

This is a valid proposal for proliferative and non-proliferative retinopathies, and there is no need for the presence of conditions such as pre-retinal neovascularization or bleeding, or retinal microaneurysm prior to IV tPA. However, if a symptom occurs, it should be handled with care and urgency.

Question: Is a vascular intervention within the last 7 days from a site that cannot be compressed a contraindication for IV tPA?

Answer: Venous/arterial interventions that have been performed in the last week and are unavailable to be compressed are considered as "warning" on the FDA label (11) and "exclusion criteria" in the AHA guideline (3). The most common scenarios in this context are central venous catheterizations made through the internal jugular or subclavian veins. This situation is written as "in the last 10 days ... access to a large vessel (e.g. subclavian vein or jugular vein puncture) that cannot be compressed ..." in the label for use in Turkey. If this patient is already in the intensive care unit, IV tPA is almost never/cannot be practiced due to comorbid diseases and conditions. In fact, tPA response, i.e. the benefit/loss ratio, of severely ill patients has not been tested at all. Other scenarios, however, include cardiac pacemaking, dialysis, pulmonary artery catheterization, and transcatheter aortic valve replacement. In these patients, the NINDS study exclusionary criterion "Avoid IV tPA" was taken as an expert opinion, but the patient experience was limited later. Therefore, in this case, it should be decided by individualizing (25).

Question: Can systemic thrombolytic therapy be used for acute strokes during angiography or endovascular procedures?

Answer: Arterial interventions made from uncompressible regions are written as contraindications in the instructions for use. Stroke risk during/after cerebral and coronary angiography are reported as $0.05-0.1 \%$, and 0.18 to $0.44 \%$, respectively. The use of IV tPA in the treatment of strokes associated with these procedures may lead to hemorrhage in the femoral access site and occasionally retroperitoneal hemorrhage. Most of these complications are also treated through endovascular methods. The fact that a significant proportion of these patients uses heparin and antiaggregant medications also poses a risk for IV tPA. For this reason, it is necessary to make a case-level assessment and it is recommended that the temporal proximity of the procedure should not be used as an exclusion criterion in advance.

Question: Can IV tPA be administered in patients with stroke who have a history of major trauma within the last 14 days?

Answer: Major trauma within the last 14 days is indicated as a contraindication to IV tPA on the FDA label (11). This part is written as "Major surgery or a major trauma (including any trauma associated with recent heart attack) within the last 10 days, recent head or brain trauma" in Turkey label of use (4). The risk of bleeding and the level of control of the trauma are determined in the IV tPA decision because there is no clearance in this article. It would be wrong to automatically assume "new major systemic trauma" as an absolute contraindication and not to assess the patient.

Question: Can IV tPA be performed in patients with stroke who have major surgical history within the past 14 days?

Answer: Although major surgeries such as coronary by-pass, as well as surgeries in very different spectra, such as birth and organ biopsy, are indicated as "warning" in FDA label, almost all are written as "relative contraindications" in the AHA guideline $(3,11)$.

However, the clinical importance of this criterion, which has been substituted from the NINDS and ECASS studies, and indeed the above-mentioned analogues, is not clear. It is not clear what is meant by the word "major" and why there is a clear "time threshold value" such as " 14 days", and this is only an expert opinion. This limit being 14 days for NINDS and 3 months for ECASS is compatible with selective nature. The main reasons for this limitation are problems related with surgical site hemorrhage. In that case, this generalization must have a heterogeneous structure with many exceptions. In accordance, the use of IV tPA has been published in the literature for post-operative stroke in the last 2-12 weeks following peri-anal surgery, cardiac pacemaking, inguinal hernia repair, gynecologic tumor resection, coronary bypass, aortofemoral bypass, colon resection, splenectomy, femur neck fracture, ankle fracture and blepharoplasty $(26,27,28)$. In these procedures, there was no permanent neurologic problem caused by IV tPA. Surgical site hemorrhage was seen, but it was usually successfully manipulated (26). Therefore, in this case, it is appropriate to individualize the case and decide on the benefit of IV tPA and the risk of hemorrhage at the surgical site (1). Having undergone 'new' and 'major' surgery is not a definite exclusion criterion.

Question: Is acute IV tPA safe for patients with thrombocytopenia $\left(<100,000 / \mathrm{mm}^{3}\right)$ ? Can IV tPA be given without a platelet result?

Answer: In all studies and guidelines, platelet counts below $100,000 / \mathrm{mm}^{3}$ were considered as contraindications and exclusion criteria for systemic thrombolytic administration $(3,4,11,29,30)$ This acceptance is not a researched subject but rather an expert opinion. It is based on the assumption that patients with thrombocytopenia will have a greater risk of hemorrhage after tPA. The 100,000 limit is also an expert prediction.

However, it is necessary to work in the laboratory for a complete blood count. Even in the best-case scenario, it means a significant loss of time. Simultaneous study with other necessary tests and treatments were considered to prevent the waiting period, but about $70 \%$ of patients were expected to wait for platelet results (a mean of 22 minutes) before IV tPA was given. Waiting is not a situation that can be solved quickly/systematically. The likelihood of having thrombocytopenia $\left(<100,000 / \mathrm{mm}^{3}\right)$ in clinically unsuspected cases was reported as $0.3-05 \%(31,32)$. Symptomatic 
ICH rate after IV tPA was reported as $7.7 \%$ in 26 patients with mild thrombocytopenia (between $50,000-100,000 / \mathrm{mm}^{3}$ ) in the literature and it is not different from non-thrombocytopenic patients (33). Taken together, if the platelet count is known to be below $100,000 / \mathrm{mm}^{3}$, IV tPA should not be given and the patient should be referred for thrombectomy if possible. It may be considered that it is not sensible to miss the tPA chance thinking that the platelet count is low if there is no clinical suspicion. The statement that IV tPA can be initiated without waiting for platelet counts in cases without clinical suspicion in the AHA guideline supports this view (3).

\section{Question: Can IV tPA be administered to patients who are using aspirin or other anti- antiaggregant drugs?}

Answer: Stroke and IV tPA use were not uncommon when using antiaggregant drugs, and about one-third of patients in NINDS, ECASS-III, and IST-3 were using aspirin (1). All guidelines include the statement that IV tPA can be used or is not contraindicated in the treatment of acute ischemic stroke occurring during aspirin or other antiaggregant (anti-platelet) agent use. This includes patients receiving high-dose aspirin and dual antiplatelet therapy. This situation is stated as "patients previously treated with aspirin have a higher risk of intracranial hemorrhage. It should not be given more than $0.9 \mathrm{mg}$ alteplase $/ \mathrm{kg}$ dose (maximum $90 \mathrm{mg}$ ) considering that the risk is high" in the instructions for use in Turkey (4).

It has been noted in large non-randomized patient series that patients with antiaggregant use may have increased hemorrhage rates with IV tPA. For example, symptomatic ICH risk of SITSISTR, consisting of 31627 cases, was found 1.8 times higher with antiaggregant monotherapy and 3.2 times higher with dual (ASA + clopidogrel) treatment (12). However, it is useful to note that the probability of ischemic stroke under dual antiplatelet treatment is low and the number of patients in the series was very low. Approximately $45 \%$ of the 85072 patients in the GTWG database were treated with IV tPA while on antiaggregant treatment, with symptomatic ICH showing a mild but significant increase in these patients. Hemorrhage in patients receiving antiaggregant treatment was $1.3 \%$ more $(5.0 \%$ versus $3.7 \%)$ and the risk was 1.18 times higher (95\% CI: 1.10-1.28). In this study, symptomatic cerebral hemorrhage after tPA showed a $0.68 \%$ increase (1.19fold) in 15116 patients using aspirin and $1.67 \%$ (1.47-fold) in 2397 patients receiving aspirin plus a clopidogrel combination, who were registered after 2012. However, receiving antiaggregant treatment before IV tPA did not increase in-hospital mortality. On the other hand, the chances of becoming ambulatory in patients receiving antiaggregant treatment were $2.23 \%$ (benefit 1.13 -fold) higher. When leaving the hospital, the mRS 0-1 ratio was $27.8 \%$ in the antiaggregant group and $24.1 \%$ in the other group. That is, although there was an insignificant increase in hemorrhage risk with the antiaggregant treatment, the clinical outcome in these patients was at a better level or at least not negatively affected (34). Although there was no association between antiplatelet use and IV tPA efficacy in the NINDS randomized controlled trial (35), similar to the above observations, receiving antiaggregant treatment during stroke $(\mathrm{n}=1562)$ increased good prognostic outcomes 1.2 times compared with not receiving antiaggregant treatment $(n=1473)$ in IST-3 (9). Similar results were obtained from the meta-analyses examining the subject: hemorrhage rate increases slightly (1.5 times), but clinical benefit continues $(36,37,38,39)$.

In the literature, there is no comparable analysis for the relationship between aspirin dose, prasugrel and ticagrelor and the risk of hemorrhage due to IV tPA. In this case, similarly, the anticipation that clinical outcomes will not be adversely affected with the increase in risk of hemorrhage is rational (37).

Antiaggregant drugs were not allowed within the first 24 hours after IV tPA administration in studies with positive results such as NINDS, ECAS-III, and IST-3. It is also not recommended in all guidelines. This situation was phrased, as "Along with this regimen, safety and efficacy of concurrent administration of heparin and aspirin within the first 24 hours after the emergence of symptoms are not sufficiently explored. For this reason, aspirin or IV heparin should not be given within the first 24 hours after Actilyse ${ }^{\circledR}$ treatment. If heparin is required due to other conditions, the dose should not exceed 10,000 international units daily administered subcutaneously." under the heading "additional therapies" in Actilyse ${ }^{\circledR}$ label for use in Turkey (4). In the randomized ARTIS study, which investigated this subject in different ways, 322 patients who received $300 \mathrm{mg}$ IV aspirin 90 minutes after tPA were compared with 320 untreated patients. The study was discontinued due to the high rate of symptomatic hemorrhage in the aspirin group ( $4.3 \%$ to $1.6 \%$ ). There was also no indication that the use of ASA could improve outcomes (mRS 0-2 ratio was $54 \%$ in the ASA group and $57.2 \%$ in the non-ASA group) (40). On the other hand, the use of parenteral glycoprotein IIb/IIIa inhibitors in combination with IV tPA in cases of acute ischemic stroke is also not recommended due to the high risk of hemorrhage and uncertainty of efficacy.

\section{Question: Can IV tPA be used in patients with high INR and/or aPTT?}

Answer: According to the current guidelines, patients using warfarin do not receive IV tPA if their INR is over $1.7(3,11)$. These limits are determined as 1.3 in the Turkish label, probably after being adapted from the user guide in England $(4,41)$. INR 1.7 usually appears as a drug effect, and liver failure, sepsis, and other non-medication coagulopathies often fall below this value (1). How to evaluate the situation in the case of a non-warfarinrelated increased INR has not been studied. It is reasonable to individualize the risk-benefit ratio, albeit with a view to treating these patients in a similar way.

In the literature, symptomatic ICH after IV tPA was seen in only 1 out of 115 published cases with INR >1.7 (1). Good clinical outcomes tended to be higher with IV tPA [OR: 1.21, CI: (0.82-1.799); $\mathrm{p}=0.001]$ in 138 of the 2755 cases with an INR of $>1.7$ (warfarin use in 14) included in the VISTA database (19).

It is suggested that IV tPA should not be applied when the aPTT is over 40 seconds, although different cut-off values are given in the guidelines in acute stroke. Although not indicated in the instructions for use of our country, being substituted directly from the inclusion criteria of NINDS study (2), it has been expressed as heparin administration within 48 hours before the onset of stroke 
and a high active partial thromboplastin time (aPTT) (4). In other words, it is recommended that no application is carried out in case of exceeding normal limits. In the literature, 164 patients with prolonged aPTT (Aptt >39 seconds in 139). Symptomatic $\mathrm{ICH}$ was seen in 6 of these patients (1). However, despite these high rates of hemorrhage, there was a significant increase in the likelihood of good clinical outcome [OR: 1.57, 95\% CI: (1.022.41)].

Therefore, even if the hemorrhage rates increase in patients with both high INR and aPTT, this does not always mean that the clinical presentation will be worse. Case-level assessment makes sense because there are no studies involving a high number of patients focused on this topic. In these patients, thrombectomy is always a reasonable alternative. On the other hand, IV tPA administration following fixation by factor, protamine sulphate, and fresh frozen plasma have not been adequately investigated.

\section{Question: Is IV tPA safe in patients using} warfarin with an INR of $<1.7$ ?

Answer: IV tPA can be given within the first 3 hours when the use of warfarin is subtherapeutic and the INR value is above normal but below 1.7. Even if the INR is normal in patients during the 3-4.5 h period, IV tPA treatment is an ECASS-III exclusion criteria if the patient has a history of regular oral anticoagulant use.

The risk of symptomatic ICH has not been studied with randomized methods in these patients. There are those who report an increased risk of hemorrhage (up to 15 -fold) in case series, as well as those who found no significant changes $(42,43,44)$. In some series, recanalization rates are noted to be slightly elevated, but we can say that the clinical use of IV tPA does not change in patients with high INR (42).

At least $50 \%$ of patients with symptomatic hemorrhage after IV tPA who had slightly elevated INR showed a significant increase in INR values after treatment (43). Detection and correction of this condition can decrease hemorrhage rates after treatment.

Question: Is it absolutely necessary to see INR values before IV tPA in a patient whose history has no suspicion of high INR?

Answer: The use of warfarin, heparin or other coagulopathic drugs, metastatic cancer, hematologic malignancies, end-stage renal failure, sepsis, shock, heart failure, disseminated intravascular coagulation, liver failure, and cirrhosis are the conditions in which prothrombin time (aPTT) and INR elevation should be suspected. In the absence of such conditions, when elevated INR is unexpected, INR above 1.7 is at $0.4 \%$ (45). Therefore, in the AHA/American Stroke Association (ASA) acute stroke guideline, it is stated that it is not required to wait for laboratory tests and IV tPA may be applied if there are no conditions causing abnormalities in the test (3).

In patients receiving warfarin, delay occurs with waiting for INR results, but this is necessary. In this case, the use of INRmeters is recommended, allowing the bedside measurement of INR. With these methods, the waiting period can be reduced by at least half $(46,47)$.
Question: What strategy should be used for IV tPA administration in patients undergoing ischemic stroke while receiving a direct thrombin inhibitor?

Answer: Active strategies for IV tPA treatment in stroke reporting the use of a direct thrombin inhibitor (e.g., dabigatran) within the last 48 hours are being developed to neutralize the drug effect by antidote (idarucizumab) or to detect the drug effect through specific hematologic tests.

First of all, it is important to note that direct thrombin inhibitor drugs are additive to tPA and are likely to show a relatively better course in these patients. Argatroban, a parenteral direct thrombin inhibitor, was used in addition to IV tPA in the Argatroban with Recombinant Tissue Plasminogen Activator for Acute Stroke-2 study. In this study, 29 patients received IV tPA, 30 patients received IV tPA and low-dose argatroban, and 31 patients received IV tPA and high-dose argatroban. The symptomatic ICH rates were $10 \%, 13 \%$, and $7 \%$, respectively. The rates of those with mRS $0-1$ in the third month were $21 \%, 30 \%$, and $32 \%$, respectively (48). Therefore, this combination is practical and safe and should be tested in further studies.

On the other hand, in case of an acute stroke in patients receiving dabigatran, which is an oral direct thrombin inhibitor and has been widely used for stroke prophylaxis in atrial fibrillation, a recanalization/reperfusion plan should be established by detecting and controlling the effect of dabigatran rather than predicting such an effect. If a patient has used dabigatran within the last 24 hours (this time can prolong up to 96 hours if the creatinine clearance is 30 and lower), or if the aPTT/thrombin time (TT) is prolonged and if the time of last use cannot be determined, the drug should be neutralized by administering idarucizumab $5 \mathrm{mg}$ before IV tPA. Neutralization occurs within minutes (49) and IV tPA is administered within the framework of the standard rules (50). In these patients, thrombectomy is always an effective strategy (51). Once IV tPA is initiated, aPTT/TT control should be obtained to control the neutralization. Of the 21 patients who were on dabigatran and had ischemic stroke and who were treated with IV tPA after idarucizumab in Germany, $79 \%$ benefited from IV tPA and no symptomatic ICH was seen (52). Until data are derived from randomized controlled trials, this current strategy, as shown here, is rational in the event of a stroke while taking dabigatran.

Guidelines state that IV tPA should not be given to a person receiving dabigatran within 48-hour if a specific hematologic test cannot be performed. The symptomatic $\mathrm{ICH}$ rate was about $4 \%$ in 136 patients (compiled in 3 studies) with stroke who were on dabigatran $(53,54,55,56)$.

Question: Can acute stroke be treated with IV tPA in patients using low-molecular-weight heparin?

Answer: IV tPA experience is limited in the treatment of stroke in those using these agents. Generally, low-molecularweight heparin (LMWH) is used in short-term and risky processes. The short-term bridging periods of warfarin are very risky periods for stroke recurrence. These patients have more comorbidities. Inhospital strokes are often associated with prophylactic (dose $<0.5$ 
$\mathrm{mg} / \mathrm{kg}$, once daily, with anti-FXa level of 0.2-0.5 IU/mL 4 hours before dosing) or therapeutic (dose $\geq 1 \mathrm{mg} / \mathrm{kg}$, twice daily, antiFXa level of 0.5-1.2 IU/mL 4 hours before dosing) LMWH. These laboratory parameters are not useful because the drug effect does not reflect INR or aPTT. IV tPA was used for stroke in $21 \mathrm{Spanish}$ patients who were receiving LMWH (5 therapeutic doses, 18 had the dose in the last 24 hours) and symptomatic ICH developed in 3 cases. Six patients died, and 7 patients had good functional outcomes. Compared with other cases, LMWH was found to be a factor that increased symptomatic ICH by 8.4 and mortality by 5.3 times (57). However, the low number of cases prevents generalization and further interpretation. In these patients, thrombectomy should always be considered as a safer alternative.

Question: What should be considered when using IV tPA in patients using oral factor-Xa inhibitors (apixaban, rivaroxaban, edoxaban)?

Answer: Measurement of the activity of oral factor Xa inhibitors in the door-to-needle time on a 7/24 manner is an almost impossible proposal. On the other hand, giving an automatic time interval also includes some drawbacks because the half-life time of the drugs will change with many factors including age and renal failure. In the absence of a hematologic test result in these cases, IV tPA is recommended if the last dose is taken 48 hours before. Symptomatic ICH was approximately 4\% in 186 and 38 cases (compiled in 3 trials) who had stroke while on rivaroxaban and apixaban, respectively $(53,54,55,56)$. New oral anticoagulant (NOAC) studies did not record the time of last taking of these drugs. However, the hemorrhage effect of drugs is correlated with the peak plasma level. This indicates that the riskiest period is the

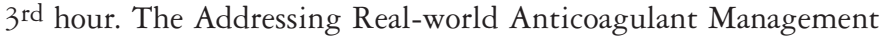
Issues in Stroke study will test this topic (58). It can be said that it is appropriate for patients taking NOAC to be evaluated for systemic thrombolysis or local thrombectomy only in stroke centers.

\section{Question: Can IV tPA be used in patients with renal insufficiency?}

Answer: The thrombotic tendency develops over very different mechanisms and the risk of hemorrhage increases due to impaired thrombocyte functions and/or increased fibrinolytic activity capacity in renal failure. Patients with end-stage renal impairment undergoing dialysis usually have a platelet count of more than $100,000 / \mathrm{mm}^{3}$; however, there is significant prolongation of bleeding time due to platelet dysfunction. Endothelial dysfunction, increased PAI-1, decreased antithrombinIII, and protein $C$ activity are seen in these patients. Kidney failure is a common condition in the clinical practice of acute stroke. For this reason, it is efficient to know that there is no contraindication to the use of IV tPA primarily for renal insufficiency and dialysis.

Out of 81070 acute stroke patients enrolled in the US national database, 1072 patients were undergoing chronic dialysis while receiving IV tPA. In this study, it was detected that hospital mortality increased after stroke [OR: 1.9, 95\% CI: (1.33-2.78)], but moderate-severe disability decreased [OR: 0.6, 95\% CI: (0.43$0.81)]$ in these patients. However, in the absence of tPA, dialysis is similarly seen as a factor that increases hospital mortality (14).
Increased symptomatic hemorrhage rates with tPA administration in patients undergoing dialysis were not seen in this study (5.2\%) (14).

It has also been reported that in-hospital mortality is slightly higher in patients with milder renal insufficiency (GFR $<60 \mathrm{cc}$ ) $\mathrm{min} / \mathrm{m}^{2}$ ). GFR was found abnormal in 15191 (34\%) of the 44410 IV tPA patients in the GTWG data bank. In these patients, GFR reduction correlated with in-hospital mortality [OR: 1.22, 95\% CI: (1.14-1.32)] and poor functional outcome at discharge [OR: 1.13, 95\% CI: (1.07-1.19)]. However, the reason for this increase was not fully revealed because there was no increase in hemorrhage rate with low GFR (59).

It was also noted in smaller series that the short-term prognosis of post- IV tPA stroke was slightly worse if renal failure was present. However, except for one study, there was no association between low GFR and increased risk of hemorrhage $(14,59,60)$.

Question: Can IV tPA be used in liver failure and cirrhosis?

Answer: In liver dysfunction and liver diseases, both procoagulant and anticoagulant pathways are abnormal. Decreased coagulation factors (factors 2, 5, 7, 9, 10, 11 and 12), thrombocyte dysfunction, fibrinogen abnormalities, hyperfibrinolysis and thrombocytopenia may lead to hemorrhage tendency after tPA. On the other hand, an intrinsic prothrombotic state develops because protein $\mathrm{C}$, protein $\mathrm{S}$ and anti-thrombin synthesis will also deteriorate in the liver. As a result, PTZ/INR and aPTT prolongation can give information about the total effect. Hyperfibrinolysis may be very prominent, especially in end-stage cirrhosis. Literature data on the use of IV tPA in these patients are not at a level to help make recommendations. Portal hypertension and esophageal varices create additional hemorrhage risk.

Question: Can IV tPA be given for stroke if there is gastrointestinal or genitourinary system hemorrhage within the last 21 days?

Answer: Active internal (gastrointestinal or genitourinary system) hemorrhages are exclusion criteria in the 2013 AHA and FDA guidelines and NINDS studies. However, if the gastrointestinal or genitourinary system hemorrhage is recent (within the last 3 weeks), it is indicated as "warning" in the instructions for use. There is no such warning in European guidelines (25).

There was no recurrence of gastrointestinal or genitourinary system hemorrhage when IV tPA was applied in a small number of patients in the literature $(27,36)$. In particular, if the hemorrhage has occurred before 1 week and has been successfully treated, worsening or recurrence with IV tPA is very unlikely (1). However, it is clear that more experience is needed to make generalizations. It is advisable to note that the benefit/loss ratios of IV tPA administration should be evaluated for individual patients with internal hemorrhage due to malignancy, gastrointestinal ulcer, esophageal varices, and that it is not an absolute contraindication.

Question: Is menstruation or menorrhagia contraindication for IV tPA? 
Answer: This is not specifically covered in the instructions for use or guidelines, but in the context of genitourinary system hemorrhages (1). In the NINDS study, 5 menstruating women were given IV tPA (control group 4) and no significant complication was encountered. In the same study, a woman with dysfunctional vaginal hemorrhage was given IV tPA, but the need for erythrocyte transfusion with increased hemorrhage emerged. When IV tPA was given to women with active menstrual bleeding for non-neurologic indications, about $8 \%$ had an increase in hemorrhage size that would require transfusion but this was not a major problem for most patients (61). Therefore, we can say that menstruation is not a contraindication to the use of IV tPA in acute stroke (1). Monitoring of vaginal bleeding after treatment is necessary.

Question: If AMI is present with acute ischemic stroke, is IV tPA given?

Answer: Ischemic stroke with AMI was an exclusion criterion in the NINDS studies. Although a history of AMI within the last 3 months is not mentioned in the FDA instructions, it has been noted as a relative exclusion criterion in the AHA guideline.

IV tPA doses are different for AMI and acute ischemic stroke. For example, in an adult weighing $70 \mathrm{~kg}, 63 \mathrm{mg}$ of tPA is given for an acute stroke, whereas $100 \mathrm{mg}$ is given for AMI. Sixty-three milligrams is ineffective for AMI and $100 \mathrm{mg}$ is dangerous for acute stroke due to increased hemorrhage risk. Some authors suggest that patients should undergo thrombectomy following IV tPA for stroke and continue with coronary angioplasty/stenting thereafter $(1,62)$. In the event of acute stroke with AMI, IV tPA is recommended if AMI is non-STEMI or STEMI and has right heart or inferior localization. Anterior STEMI should be assessed patient specifically. IV tPA administration during AMI has the risk of embolism with fragmentation of the ventricular thrombus, hemopericardium, cardiac tamponade, and cardiac rupture at a rather low level (63).

Question: Can IV tPA be administered in patients with pericarditis?

Answer: Although pericarditis is a "warning" for tPA in the FDA label, it is not mentioned in the AHA guidelines. The risk of hemopericardium and tamponade increases with IV tPA in patients with pericarditis. However, experts in the subject agree that pericarditis is not a contraindication for IV tPA administration in major strokes (1).

Question: Is the risk of embolism increased with systemic thrombolysis in patients with intracardiac thrombosis?

Answer: Presence of thrombus in the left ventricle is not specified as exclusion criteria in the NINDS studies or in the FDA label. In this case, there is a theoretical risk of thrombotic fragmentation, mobilization or embolism with a fibrinolytic. If there is a thrombus in the left ventricle in AMI, the risk of systemic embolism after fibrinolysis is $1.5 \%$ (64).

Early systemic/cerebral embolism was not systematically studied with IV tPA use in acute stroke. Although systemic embolism with IV tPA was not observed in five intracardiac thrombi cases (2 atrial, 3 ventricular) (65), cerebral embolism, embolic AMI, or embolic lower limb ischemia has been reported after IV tPA as case reports $(66,67)$. In the AHA guidelines, it is suggested that IV tPA should be initiated with major ischemic syndromes, even if left ventricular thrombosis is diagnosed, and that the management should be individualized with a benefit-toloss ratio in cases with moderate-to-mild symptoms $(1,3)$.

Question: Can IV tPA be given in infected endocarditis-related strokes?

Answer: Subacute bacterial endocarditis is a warning for IV tPA in the FDA label. However, it was not included in NINDS studies and AHA guidelines as exclusion criteria. Theoretically, tPA should be effective as thrombus has an important proportion in the structure of septic emboli. However, the hemorrhagic tendency is very high because of septic arteritis or infectious vasculitis. In other words, the fact that the mycotic aneurysm is not shown by DSA cannot reduce this increased risk of hemorrhage to reasonable levels. In the literature, IV tPA was used in 8 cases of ischemic stroke with infective endocarditis and hemorrhage was detected in 7 cases (1). The use of IV tPA is at risk in infective endocarditis and is not recommended (11).

\section{Question: Does intracardiac mass impede the administration of IV tPA?}

Answer: Intracardiac non-thrombotic masses (myxoma, fibroelastoma) have not been mentioned as contraindications in the current guidelines with NINDS studies. Embolic stroke is common in left atrial myxomas. In these patients, relatively typical distal fusiform cerebral aneurysm formation and $\mathrm{SAH}$ are also not uncommon. A response to IV thrombolytic therapy may be expected because embolic material contains tumor tissue and cells as well as thrombus. This issue has been examined in the literature as a case series. In a study in which 15 patients were evaluated, the rate of bleeding in the first 24 hours was $13 \%$ (2 patients); 19 patients had no symptomatic ICH $(1,68)$. Papillary fibroelastoma is not a contraindication in the context of IV tPA use. There was no hemorrhage with IV tPA in two patients with valvular fibroelastoma (1).

Question: Can IV tPA be administered in a patient with diagnosed or suspected aortic dissection?

Answer: If aortic dissection is related to cervical arteries, it may also be a direct stroke cause. There is a risk of aortic rupture after IV tPA if aortic dissection is documented with clinical and radiologic findings or if there is strong suspicion. The general opinion is that tPA should not be applied in these situations (1). However, in the literature, there are case reports in which Stanford type A dissections were later detected and no complications were observed related to IV tPA $(69,70)$. Aortic dissection should be suspected in patients with severe back and chest pain, diaphoresis, hypotension, cardiogenic shock, no pulse or coldness in the lower limbs, or blood pressure difference between the upper and lower or right-left before or after tPA. 


\section{Question: Can IV tPA be given in cases of known malignancy?}

Answer: IV tPA should be used for acute ischemic stroke treatment in cases of malignancy. The presence of cancer does not constitute a contraindication to tPA. Cancer is a poor prognostic factor in itself, but it does not undermine this recommendation. According to some experts, there should be a minimum of 3 or 12 months of life expectancy and a reasonable quality of life for IV tPA to be administered to patients with cancer.

In many case-control series involving active or recurrent cancer without brain metastasis, IV tPA for acute stroke has not been associated with an increase in intracranial and systemic hemorrhagic complications, which suggests that it is safe $(71,72,73,74)$.

\section{Question: Can tPA be used in pregnant women?}

Answer: It is noted in the FDA label that pregnancy and postpartum period are risky for the administration of tPA in the event of stroke and that it is necessary to evaluate the benefit-loss ratio individually for the patient. This situation features in the same way in the Turkish user manual (4).

Alteplase is in category $\mathrm{C}$ in pregnancy. It shows an embryocidal effect at high doses. However, animal studies did not show fetal toxicity or teratogenicity at $1 \mathrm{mg} / \mathrm{kg}$ doses. These may be indirect data showing that these clinical doses may be safe. Therefore, hemorrhage is the major risk for the use of tPA in pregnancy.

There is no satisfactory quality and reliable data on the use of IV tPA in pregnancies. In an analysis performed in 2014, 12 pregnant women ( 8 in the first trimester, 2 in the second trimester, and 2 in the third trimester) who were administered IV tPA were evaluated and it was found that the majority of the cases were M1 or M2 occlusions and NIHSS was between 6-25. Six patients had IV tPA only and the other 6 patients underwent additional interventional treatments. Symptomatic cerebral hemorrhage developed in 2 patients in this series. One of the cases was mortal and an intra-arterial procedure was also performed. Systemic hemorrhage occurred in 2 of the women who had IV tPA only; one of these hemorrhages was intrauterine and caused the termination of pregnancy. Two of the twelve fetuses died, two were terminated medically, and eight were born healthy (1).

Pregnancy has been accepted as a relative exclusion criterion in the AHA guidelines. That is, it is possible to apply tPA in pregnancy after making a careful evaluation and taking into account the benefits and risks (3).

Question: Can IV tPA be used in patients with significant pre-stroke disability and dependence?

Answer: Pre-stroke disability is not an exclusion criterion for tPA in the FDA, AHA, and Turkish instructions for use and guidelines. However, it cannot be denied that the degree of disability and the level of functionality before stroke and life expectancy along with the number and severity of comorbidities, such as age and staying in a nursing home, are factors that are effective and determinant in the treatment decision-making process by a neurologist.

Pre-stroke disability is generally considered to be $m R S \geq 2$ and is associated with both worse outcomes and long-term hospitalization.
Pre-stroke disability and dependence in the stroke population increases with age, as expected, and is detected in approximately one-third of patients. Patients with significant pre-stroke disability were excluded from fundamental IV tPA studies. In the NINDS trial, only $48(7.7 \%)$ patients with previous disability were included. These patients were older, more diabetic, and had more severe clinical manifestations, and, congruently, they had a lower rate of good functional outcomes ( $25 \%$ vs. $52 \%$ ). Compared with placebo, tPA is also useful in these patients (good prognosis at 3 months is $25 \%$ in the tPA group and $12.5 \%$ in the placebo group) (75).

In patients with severe pre-existing disability in the case series, the rate of mortality and worse function remained high and the patients were unable to return to their pre-stroke level of function despite IV tPA administration (76).

The dichotomized approach, namely determination of independence (mRS 0-2) or absence of disability (mRS 0-1) in patients, is not realistic in patients with pre-existing disability, and the outcome assessment should be performed through mRSshift analysis. Providing better outcomes with IV tPA in patients with pre-existing disability was demonstrated in both the NINDS [OR: $1.60 ; 95 \% \mathrm{CI}:(1.21-2.11)]$ and ECASS-II trials [OR: 1.32; 95\% CI: (1.02-1.71)] by following this method (77).

Eleven percent of the 5995 patients in the SITS-EAST database had pre-stroke mRS 1, $4 \%$ had pre-stroke mRS 2, and $2 \%$ had pre-stroke $\mathrm{mRS} \geq 3$. Although the post-stroke mortality rate remained higher in these patients (1.3-fold in mRS 1, 2-fold in mRS 2, and 2.6-fold in mRS 3 compared with the mRS 0 group), it was determined that there was no difference in symptomatic hemorrhage and returning to pre-stroke mRS value with mRSshift analysis (78).

In the case of an ordinary stroke, a healthy life span of 4 years and 5 months is provided with IV tPA. This period is also a minimum of 1 year and 3 months when there is a significant preexisting disability (79). In short, it is reasonable to apply IV tPA for acute stroke in patients who had pre-existing disability but who can also at least stand with help (1).

Question: Can patients staying in nursing homes receive IV tPA during stroke?

Answer: Although patients who live permanently in nursing homes are excluded from randomized trials, IV tPA application in mobile patients is rational. However, because of the prejudice of health systems in which neurologists are also involved, the rate of tPA administration in patients from health care institutions in the nursing home category is about 4 times lower (80). This situation does not comply with scientific and ethical principles. However, it can be considered to enter the consent-making process by taking into consideration factors such as the social support of these patients, the view of the family members, the characteristics of the referral health institution, and individual factors.

Question: Is IV tPA administered in terminally ill patients?

Answer: It is stated that it is appropriate to have at least 1-year life expectancy for IV tPA administration (3). However, 
many authors believe that "thrombolytic/thrombectomy should be offered if these patients have a life expectancy of 6 or at least 3 months" (81). Metastatic cancers constitute the majority of patients who have shorter life expectancy and who are in mobile condition. It should never be forgotten that tPA activity is assessed on the $90^{\text {th }}$ day when the decision is made in this group.

\section{Question: How should IV tPA administration be evaluated in the event that there was no stroke?}

Answer: Stroke mimics are very diverse and are important because they can expose the patient to hemorrhagic and allergic complications of IV tPA administration. The necessity of applying post-IV tPA maintenance metrics is also problematic. Diffusionweighted magnetic resonance imaging (MRI) in these patients is negative. The frequency of stroke mimics in tPA series is not uncommon, but varies (between 1-25\%). This is not a medical error. In general, the incidence of IV tPA hemorrhage complications in these cases is much lower than in patients with acute stroke (approximately 1\%) $(82,83,84)$. For this reason, avoiding tPA is not the right approach in uncertain situations.

In a study involving a large number of centers from 12 countries and involving 5581 IV tPA patients in Europe, it was understood that 100 patients $(1.8 \%)$ did not have a stroke. The final diagnosis of these patients was epileptic seizures (41\%), psychogenic diseases (28\%), migraine (12\%), demyelination $(5 \%)$, encephalitis (3\%), brain tumors (2\%), peripheral vestibulopathy $(1 \%)$, posterior reversible encephalopathy syndrome (1\%), brachial plexopathy (1\%), hypoglycemia (1\%), sinusitis (1\%), intoxication (1\%), cervical spinal hemorrhage $(1 \%)$ and idiopathic non-vascular syndrome (2\%). These patients are younger, and the frequency of vascular risk factors other than smoking is lower and the rate in women is higher. The symptomatic ICH rate is $1 \%$ (95\% CI: $0.0-5 \%$ ). The only bleeding case was a 76-year-old patient with epilepsy who developed homonymous hemianopsy and recovered considerably after 3 months. The symptomatic hemorrhage rate with IV tPA was $7.9 \%$ in true stroke patients analyzed in the same series (82). It is worth noting that $75 \%$ of the 100 patients in this series fully recovered. Deaths were incidental.

The most common stroke mimics leading to psychogenic pseudo-neurological deficits are conversion, somatization, or malingering mimics. IV tPA may have been given in these cases because the decision-making period is also limited. However, symptomatic cerebral hemorrhage with IV tPA has not been published in the literature.

One of the most common stroke mimics is "recrudescence" or "re-exacerbation." This is "partly" reappearance of previously resolved symptoms of ischemic stroke for a period of time due to infection, various medications, renal insufficiency, and disorders of glycemia. In the California series, it was reported as $11 \%(\mathrm{n}=104)$ among stroke mimics. Aphasia, confusion and amnesia are more frequent in these patients (83).

Question: In which case should brain MRI be performed to patients who are candidates for thrombolytic therapy?
Answer: Routine MRI is not required prior to IV thrombolytic therapy. If diagnostic problems persist after brain CT, diffusionweighted MRI may be required. Penumbra and its equivalents can be determined by performing MRI to detect diffusion-clinical mismatch, diffusion-FLAIR mismatch, or diffusion-MRI perfusion mismatch in patients when the time of stroke is uncertain.

Question: Is IV tPA necessary for every patient with a thrombectomy plan? Can the indication of thrombectomy only be made through vascular imaging? Should tPA dose be standard for patients with planned thrombectomy?

Answer: The answer to all of these questions is 'yes'. With 9 randomized controlled trials published after November 2014, neuro interventional recanalization of acute cerebral large vascular occlusions (terminal internal carotid artery, middle cerebral artery proximal segments and basilar artery) became standard practice (85). This method is probably also useful in the occlusion of the M2 (86). The most popular recanalization methods are aspiration (a direct aspiration first-pass technique-ADAPT) and/ or stentriever thrombectomy (85). Early recanalization with IV tPA in occlusions of these major arteries is less than $30 \%$ (87). In endovascular treatment, however, this rate is over $80 \%$, and NNT is at a low level of 2.5 in order to rescue a patient (85).

Patient randomization was performed based on emergency CT and CT angiography in all trials in which the success of these methods was demonstrated (85). Large vessel occlusion can only be diagnosed using CT angiography and similar vascular imaging. CT angiography is the basic diagnostic tool of acute stroke management practice and should be seen as a minimum. Therefore, CT angiography should be performed as long as there is no contraindication for CT. This method should be used 24/7 in centers that treat stroke (88).

The presence of large vessel occlusion increases as NIHSS increases (89). A number of clinical scoring systems were performed by combining the findings of the physical examination and anamnesis to diagnose large vessel occlusions and to triage these patients to stroke centers. For example, the RACE scale for Stroke is based on the physical examination: The presence of facial palsy (0-2), arm and leg motor impairment (0-2 each), head and gaze deviation (0-1) and aphasia/agnosia (0-2) is evaluated and the probability of large vessel occlusion increases when the score is $\geq 5$ out of 9 (sensitivity: $85 \%$ and specificity: 68\%) (90,91). However, the performance of these scores, which are more than 15 , is rather low and they cannot replace vascular imaging $(92,93)$.

In the case-level meta-analysis of the first five published studies [HERMES study (94); $\mathrm{n}=1287$ ], it was found that $83 \%$ of patients who underwent mechanical thrombectomy received IV tPA. All patients in the latter studies received IV tPA (85). Patients who did not receive IV tPA treatment had a contraindication for systemic thrombolysis. In the control group, $87 \%$ of patients received IV tPA. Subgroup analyses indicated that thrombectomy was also an effective method in patients who did not receive IV tPA. However, in order for thrombectomy to become a gold standard or an alternative alone, its effectiveness against the combination therapy must also be demonstrated by randomized controlled trials (95). Nowadays, 
it should be known that standard and full dose IV tPA should be administered within the first 4.5 hours to any patient who will undergo thrombectomy and with no contraindications. IV tPA doses of $0.6 \mathrm{mg} / \mathrm{kg}$ are not successful and should not be recommended (96).

\section{Ethics}

Peer-review: Externally peer-reviewed.

\section{Authorship Contributions}

Surgical and Medical Practices: M.A.T., E.M.A., A.Ö.Ö., E.G., D.N.Ö., Ş.Ö., Concept: M.A.T., E.M.A., A.Ö.Ö., E.G., D.N.Ö., Ş.Ö., Design: M.A.T., E.M.A., A.Ö.Ö., E.G., D.N.Ö., Ş.Ö., Data Collection or Processing: M.A.T., Analysis or Interpretation: M.A.T., E.M.A., A.Ö.Ö., E.G., D.N.Ö., Ş.Ö., Literature Search: M.A.T., E.M.A., A.Ö.Ö., E.G., D.N.Ö., Ş.Ö., Writing: M.A.T., E.M.A., A.Ö.Ö., E.G., D.N.Ö., Ş.Ö.

Conflict of Interest: All authors have taken part in Scientific Advisory Board of Boehringer Ingelheim Turkey on tPA usage in stroke.

Financial Disclosure: The authors declared that this study received no financial support.

\section{References}

1. Demaerschalk BM, Kleindorfer DO, Adeoye OM, Demchuk AM, Fugate JE, Grotta JC, Khalessi AA, Levy EI, Palesch YY, Prabhakaran S, Saposnik G, Saver JL, Smith EE; American Heart Association Stroke Council and Council on Epidemiology and Prevention. Scientific Rationale for the Inclusion and Exclusion Criteria for Intravenous Alteplase in Acute Ischemic Stroke: A Statement for Healthcare Professionals From the American Heart Association/American Stroke Association. Stroke 2016;47:581-641.

2. National Institute of Neurological Disorders and Stroke rt-PA Stroke Study Group. Tissue plasminogen activator for acute ischemic stroke. N Engl J Med 1995;333:1581-1587.

3. Jauch EC, Saver JL, Adams HP Jr, Bruno A, Connors JJ, Demaerschalk BM, Khatri P, McMullan PW Jr, Qureshi AI, Rosenfield K, Scott PA, Summers DR, Wang DZ, Wintermark M, Yonas H; American Heart Association Stroke Council; Council on Cardiovascular Nursing; Council on Peripheral Vascular Disease; Council on Clinical Cardiology. Guidelines for the early management of patients with acute ischemic stroke: a guideline for healthcare professionals from the American Heart Association/American Stroke Association. Stroke 2013;44:870-947.

4. TCSB. ACTILYSE $50 \mathrm{mg} 1$ flakon Kullanma Talimatı PDF Dosyası. Ulaşılan web sitesi: http://wwwilacrehbericom/pdfs/actilyse-50-mg-1-flakon-870d/ kt/ 2012; Ulaşım tarihi: 21/4/2017(Boehringer Ingelheim İlaç Tic. A.Ş. Güncelleme: 7 September 2012).

5. Hacke W, Kaste M, Bluhmki E, Brozman M, Dávalos A, Guidetti D, Larrue V, Lees KR, Medeghri Z, Machnig T, Schneider D, von Kummer R, Wahlgren $\mathrm{N}$, Toni D; ECASS Investigators. Thrombolysis with alteplase 3 to 4.5 hours after acute ischemic stroke. N Engl J Med 2008; 359:1317-1329.

6. Bhatnagar P, Sinha D, Parker RA, Guyler P, O'Brien A. Intravenous thrombolysis in acute ischaemic stroke: a systematic review and metaanalysis to aid decision making in patients over 80 years of age. J Neurol Neurosurg Psychiatry 2011;82:712-717.

7. Asuzu D, Nystrom K, Amin H, Schindler J, Wira C, Greer D, Chi NF, Halliday J, Sheth KN. Comparison of 8 scores for predicting symptomatic intracerebral hemorrhage after IV thrombolysis. Neurocrit Care 2015;22:229-233.

8. Mishra NK, Diener HC, Lyden PD, Bluhmki E, Lees KR; VISTA Collaborators. Influence of age on outcome from thrombolysis in acute stroke: a controlled comparison in patients from the Virtual International Stroke Trials Archive (VISTA). Stroke 2010;41:2840-2848.

9. IST-3 collaborative group, Sandercock P, Wardlaw JM, Lindley RI, Dennis M, Cohen G, Murray G, Innes K, Venables G, Czlonkowska A, Kobayashi A, Ricci S, Murray V, Berge E, Slot KB, Hankey GJ, Correia M, Peeters A, Matz K, Lyrer P, Gubitz G, Phillips SJ, Arauz A. The benefits and harms of intravenous thrombolysis with recombinant tissue plasminogen activator within $6 \mathrm{~h}$ of acute ischaemic stroke (the third international stroke trial [IST3]): a randomised controlled trial. Lancet 2012;379:2352-2363.

10. Emberson J, Lees KR, Lyden P, Blackwell L, Albers G, Bluhmki E, Brott T, Cohen G, Davis S, Donnan G, Grotta J, Howard G, Kaste M, Koga M, von Kummer R, Lansberg M, Lindley RI, Murray G, Olivot JM, Parsons M, Tilley B, Toni D, Toyoda K, Wahlgren N, Wardlaw J, Whiteley W, del Zoppo GJ, Baigent C, Sandercock P, Hacke W; Stroke Thrombolysis Trialists' Collaborative Group. Effect of treatment delay, age, and stroke severity on the effects of intravenous thrombolysis with alteplase for acute ischaemic stroke: a meta-analysis of individual patient data from randomised trials. Lancet 2014;384:1929-1935.

11. FDA. ACTIVASE (alteplase) for injection, for intravenous use HIGHLIGHTS OF PRESCRIBING INFORMATION. Application 103172 This document contains: Label for ACTIVASE [Supplement 5203, Action Date 02/13/2015] 2015; https://www.accessdata.fda.gov/drugsatfda_docs/ label/2015/103172s52031bl.pdf (accessed on april 20, 2017).

12. Mazya M, Egido JA, Ford GA, Lees KR, Mikulik R, Toni D, Wahlgren $\mathrm{N}$, Ahmed N; SITS Investigators. Predicting the risk of symptomatic intracerebral hemorrhage in ischemic stroke treated with intravenous alteplase: safe Implementation of Treatments in Stroke (SITS) symptomatic intracerebral hemorrhage risk score. Stroke 2012;43:1524-1531.

13. Menon BK, Saver JL, Prabhakaran S, Reeves M, Liang L, Olson DM, Peterson ED, Hernandez AF, Fonarow GC, Schwamm LH, Smith EE. Risk score for intracranial hemorrhage in patients with acute ischemic stroke treated with intravenous tissue-type plasminogen activator. Stroke 2012;43:2293-2299.

14. Tariq N, Adil MM, Saeed F, Chaudhry SA, Qureshi AI. Outcomes of thrombolytic treatment for acute ischemic stroke in dialysis-dependent patients in the United States. J Stroke Cerebrovasc Dis 2013;22:354-359.

15. Brott T, Lu M, Kothari R, Fagan SC, Frankel M, Grotta JC, Broderick J, Kwiatkowski T, Lewandowski C, Haley EC, Marler JR, Tilley BC. Hypertension and its treatment in the NINDS rt-PA Stroke Trial. Stroke 1998;29:1504-1509.

16. Desilles JP, Meseguer E, Labreuche J, Lapergue B, Sirimarco G, GonzalezValcarcel J, Lavallée P, Cabrejo L, Guidoux C, Klein I, Amarenco P, Mazighi M. Diabetes mellitus, admission glucose, and outcomes after stroke thrombolysis: a registry and systematic review. Stroke 2013;44:1915-1923.

17. Ribo M, Molina C, Montaner J, Rubiera M, Delgado-Mederos R, Arenillas JF, Quintana M, Alvarez-Sabín J. Acute hyperglycemia state is associated with lower tPA-induced recanalization rates in stroke patients. Stroke 2005;36:1705-1709.

18. Ribo M, Molina CA, Delgado P, Rubiera M, Delgado-Mederos R, Rovira A, Munuera J, Alvarez-Sabin J. Hyperglycemia during ischemia rapidly accelerates brain damage in stroke patients treated with tPA. J Cereb Blood Flow Metab 2007;27:1616-1622.

19. Frank B, Grotta JC, Alexandrov AV, Bluhmki E, Lyden P, Meretoja A, Mishra NK, Shuaib A, Wahlgren NG, Weimar C, Lees KR; VISTA Collaborators. Thrombolysis in stroke despite contraindications or warnings? Stroke 2013;44:727-733.

20. Yong M, Kaste M. Dynamic of hyperglycemia as a predictor of stroke outcome in the ECASS-II trial. Stroke 2008;39:2749-2755.

21. Newey CR, Cueva W, Vellipuram A, Hornik A. Medical Decision Making: Hyposphagma Prior to Intravenous Tissue Plasminogen Activator in Acute Ischemic Stroke. J Stroke Cerebrovasc Dis 2016;25:181-182.

22. Gunnar RM, Passamani ER, Bourdillon PD, Pitt B, Dixon DW, Rapaport E, Fuster V, Reeves TJ, Karp RB, Russell RO Jr, et al. Guidelines for the early management of patients with acute myocardial infarction. A report of the American College of Cardiology/American Heart Association Task Force on Assessment of Diagnostic and Therapeutic Cardiovascular Procedures (Subcommittee to Develop Guidelines for the Early Management of Patients with Acute Myocardial Infarction). J Am Coll Cardiol 1990;16:249-292.

23. Mahaffey KW, Granger CB, Toth CA, White HD, Stebbins AL, Barbash GI, Vahanian A, Topol EJ, Califf RM. Diabetic retinopathy should not be a contraindication to thrombolytic therapy for acute myocardial infarction: review of ocular hemorrhage incidence and location in the GUSTO-I trial. Global Utilization of Streptokinase and t-PA for Occluded Coronary Arteries. J Am Coll Cardiol 1997;30:1606-1610.

24. Moudgil SS. Thrombolysis in acute ischemic stroke with vitreous hemorrhage. Arch Neurol 2009;66:1178.

25. Fugate JE, Rabinstein AA. Absolute and Relative Contraindications to IV rt-PA for Acute Ischemic Stroke. Neurohospitalist 2015;5:110-121. 
26. De Keyser J, Gdovinová Z, Uyttenboogaart M, Vroomen PC, Luijckx GJ Intravenous alteplase for stroke: beyond the guidelines and in particular clinical situations. Stroke 2007;38:2612-2618.

27. Guillan M, Alonso-Canovas A, Garcia-Caldentey J, Sanchez-Gonzalez V, Hernandez-Medrano I, Defelipe-Mimbrera A, Matute MC, Alonso-Arias MA, Alonso de Leciñana M, Masjuan J. Off-label intravenous thrombolysis in acute stroke. Eur J Neurol 2012;19:390-394.

28. Meretoja A, Putaala J, Tatlisumak T, Atula S, Artto V, Curtze S, Häppölä O, Lindsberg PJ, Mustanoja S, Piironen K, Pitkäniemi J, Rantanen K, Sairanen T, Salonen O, Silvennoinen H, Soinne L, Strbian D, Tiainen M, Kaste M. Off-label thrombolysis is not associated with poor outcome in patients with stroke. Stroke 2010;41:1450-1458.

29. Network CS. Canadian Stroke Best Practices Management of Stroke Patients Who Receive Acute Thrombolytic Therapy (tPA) Order Set 2017. http:// www.strokebestpractices.ca/wp-content/uploads/2013/05/CSP-OS-02Management-of-Stroke-Patients-who-Receive-tPA.pdf.

30. Casaubon LK, Boulanger JM, Blacquiere D, Boucher S, Brown K, Goddard $\mathrm{T}$, Gordon J, Horton M, Lalonde J, LaRivière C, Lavoie P, Leslie $\mathrm{P}, \mathrm{McN}$ eill J, Menon BK, Moses B, Penn M, Perry J, Snieder E, Tymianski D, Foley N, Smith EE, Gubitz G, Hill MD, Glasser E, Lindsay P; Heart and Stroke Foundation of Canada Canadian Stroke Best Practices Advisory Committee. Canadian Stroke Best Practice Recommendations: Hyperacute Stroke Care Guidelines, Update 2015. Int J Stroke 2015;10:924-940.

31. Cucchiara BL, Jackson B, Weiner M, Messe SR. Usefulness of checking platelet count before thrombolysis in acute ischemic stroke. Stroke 2007;38:1639-1640.

32. Breuer L, Huttner HB, Kiphuth IC, Ringwald J, Hilz MJ, Schwab S, Köhrmann M. Waiting for platelet counts causes unsubstantiated delay of thrombolysis therapy. Eur Neurol 2013;69:317-320.

33. Mowla A, Kamal H, Lail NS, Vaughn C, Shirani P, Mehla S, RajabzadehOghaz H, Deline C, Ching M, Crumlish A, Sawyer RN. Intravenous Thrombolysis for Acute Ischemic Stroke in Patients with Thrombocytopenia. J Stroke Cerebrovasc Dis 2017;26:1414-1418.

34. Xian Y, Federspiel JJ, Grau-Sepulveda M, Hernandez AF, Schwamm LH, Bhatt DL, Smith EE, Reeves MJ, Thomas L, Webb L, Bettger JP, Laskowitz DT, Fonarow GC, Peterson ED. Risks and Benefits Associated With Prestroke Antiplatelet Therapy Among Patients With Acute Ischemic Stroke Treated With Intravenous Tissue Plasminogen Activator. JAMA Neurol 2016;73:50-59.

35. [No authors listed]. Generalized efficacy of t-PA for acute stroke. Subgroup analysis of the NINDS t-PA Stroke Trial. Stroke 1997;28:2119-2125.

36. Meseguer E, Labreuche J, Guidoux C, Lavallée PC, Cabrejo L, Sirimarco G, Valcarcel JG, Klein IF, Amarenco P, Mazighi M. Outcomes after stroke thrombolysis according to prior antiplatelet use. Int J Stroke 2015;10:163-169.

37. Pan X, Zhu Y, Zheng D, Liu Y, Yu F, Yang J. Prior antiplatelet agent use and outcomes after intravenous thrombolysis with recombinant tissue plasminogen activator in acute ischemic stroke: a meta-analysis of cohort studies and randomized controlled trials. Int J Stroke 2015;10:317-323.

38. Luo S, Zhuang M, Zeng W, Tao J. Intravenous Thrombolysis for Acute Ischemic Stroke in Patients Receiving Antiplatelet Therapy: A Systematic Review and Meta-analysis of 19 Studies. J Am Heart Assoc 2016;5:e003242.

39. Tsivgoulis G, Katsanos AH, Zand R, Sharma VK, Köhrmann M, Giannopoulos S, Dardiotis E, Alexandrov AW, Mitsias PD, Schellinger PD, Alexandrov AV. Antiplatelet pretreatment and outcomes in intravenous thrombolysis for stroke: a systematic review and meta-analysis. J Neurol 2017;264:1227-1235.

40. Zinkstok SM, Roos YB; ARTIS investigators. Early administration of aspirin in patients treated with alteplase for acute ischaemic stroke: a randomised controlled trial. Lancet 2012;380:731-737.

41. Actilyse Prescribing Information. wwwmedicinesorguk/ emc/medicine/308 2016.

42. Mazya MV, Lees KR, Markus R, Roine RO, Seet RC, Wahlgren N, Ahmed $\mathrm{N}$; Safe Implementation of Thrombolysis in Stroke Investigators. Safety of intravenous thrombolysis for ischemic stroke in patients treated with warfarin. Ann Neurol 2013;74:266-274.

43. Ruecker M, Matosevic B, Willeit P, Kirchmayr M, Zangerle A, Knoflach M, Willeit J, Kiechl S. Subtherapeutic warfarin therapy entails an increased bleeding risk after stroke thrombolysis. Neurology 2012;79:31-38.

44. Seet RC, Zhang Y, Moore SA, Wijdicks EF, Rabinstein AA. Subtherapeutic international normalized ratio in warfarin-treated patients increases the risk for symptomatic intracerebral hemorrhage after intravenous thrombolysis. Stroke 2011;42:2333-2335.

45. Saposnik G, Fang J, Kapral MK, Tu JV, Mamdani M, Austin P, Johnston SC; Investigators of the Registry of the Canadian Stroke Network (RCSN); Stroke Outcomes Research Canada (SORCan) Working Group. The iScore predicts effectiveness of thrombolytic therapy for acute ischemic stroke. Stroke 2012;43:1315-1322.

46. Dangayach NS, Panchabhai TS. Point-of-care international normalized ratio measurements to assess eligibility for thrombolysis in acute ischemic stroke: some thoughts. Stroke 2010; 41:e431.

47. Rizos T, Herweh C, Jenetzky E, Lichy C, Ringleb PA, Hacke W, Veltkamp R. Pointof-care international normalized ratio testing accelerates thrombolysis in patients with acute ischemic stroke using oral anticoagulants. Stroke 2009;40:3547-3551.

48. Barreto AD, Ford GA, Shen L, Pedroza C, Tyson J, Cai C, Rahbar MH, Grotta JC; ARTSS-2 Investigators. Randomized, Multicenter Trial of ARTSS-2 (Argatroban With Recombinant Tissue Plasminogen Activator for Acute Stroke). Stroke 2017;48:1608-1616.

49. Pollack CV Jr, Reilly PA, Eikelboom J, Glund S, Verhamme P, Bernstein RA, Dubiel R, Huisman MV, Hylek EM, Kamphuisen PW, Kreuzer J, Levy JH, Sellke FW, Stangier J, Steiner T, Wang B, Kam CW, Weitz JI. Idarucizumab for Dabigatran Reversal. N Engl J Med 2015;373:511-520.

50. Diener HC, Bernstein R, Butcher K, Campbell B, Cloud G, Davalos A, Davis S, Ferro JM, Grond M, Krieger D, Ntaios G, Slowik A, Touzé E. Thrombolysis and thrombectomy in patients treated with dabigatran with acute ischemic stroke: Expert opinion. Int J Stroke 2017;12:9-12.

51. Matute MC, Guillán M, García-Caldentey J, Buisan J, Aparicio M, Masjuan J, Alonso de Leciñana $\mathrm{M}$. Thrombolysis treatment for acute ischaemic stroke in a patient on treatment with dabigatran. Thromb Haemost 2011;106:178-179.

52. Kermer P, Eschenfelder CC, Diener HC, Grond M, Abdalla Y, Althaus K, Berrouschot J, Cangür H, Daffertshofer M, Edelbusch S, Gröschel K, Haase CG, Harloff A, Held V, Kauert A, Kraft P, Lenz A, Müllges W, Obermann M, Partowi S, Purrucker J, Ringleb PA, Röther J, Rossi R, Schäfer N, Schneider A, Schuppner R, Seitz RJ, Szabo K, Wruck R. Antagonizing dabigatran by idarucizumab in cases of ischemic stroke or intracranial hemorrhage in Germany - A national case collection. Int J Stroke 2017;12:383-391.

53. Xian Y, Federspiel JJ, Hernandez AF, Laskowitz DT, Schwamm LH, Bhatt DL, Smith EE, Fonarow GC, Peterson ED. Use of Intravenous Recombinant Tissue Plasminogen Activator in Patients With Acute Ischemic Stroke Who Take Non-Vitamin K Antagonist Oral Anticoagulants Before Stroke. Circulation 2017;135:1024-1035.

54. Tsivgoulis G, Safouris A. Intravenous Thrombolysis in Acute Ischemic Stroke Patients Pretreated With Non-Vitamin K Antagonist Oral Anticoagulants: An Editorial Review. Stroke 2017;48:2031-2033.

55. Seiffge DJ, Hooff RJ, Nolte CH, Béjot Y, Turc G, Ikenberg B, Berge E, Persike M, Dequatre-Ponchelle N, Strbian D, Pfeilschifter W, Zini A, Tveiten A, Næss H, Michel P, Sztajzel R, Luft A, Gensicke H, Traenka C, Hert L, Scheitz JF, De Marchis GM, Bonati LH, Peters N, Charidimou A, Werring DJ, Palm F, Reinhard M, Niesen WD, Nagao T, Pezzini A, Caso V, Nederkoorn PJ, Kägi G, von Hessling A, Padjen V, Cordonnier C, Erdur H, Lyrer PA, Brouns R, Steiner T, Tatlisumak T, Engelter ST; NOACISP Study Group. Recanalization therapies in acute ischemic stroke patients: impact of prior treatment with novel oral anticoagulants on bleeding complications and outcome. Circulation 2015;132:1261-1269.

56. Shahjouei S, Tsivgoulis G, Bavarsad Shahripour R, Jones GM, Alexandrov AV, Zand R. Safety of Intravenous Thrombolysis among Stroke Patients Taking New Oral Anticoagulants--Case Series and Systematic Review of Reported Cases. J Stroke Cerebrovasc Dis 2015;24:2685-2693.

57. Matute MC, Masjuan J, Egido JA, Fuentes B, Simal P, Díaz-Otero F, Reig G, Díez-Tejedor E, Gil-Nuñez A, Vivancos J, Alonso de Leciñana M. Safety and outcomes following thrombolytic treatment in stroke patients who had received prior treatment with anticoagulants. Cerebrovasc Dis 2012;33:231-239.

58. Xian Y, Hernandez AF, Harding T, Fonarow GC, Bhatt DL, Suter RE, Khan Y, Schwamm LH, Peterson ED. Acute management of stroke patients taking non-vitamin $\mathrm{K}$ antagonist oral anticoagulants Addressing Real-world Anticoagulant Management Issues in Stroke (ARAMIS) Registry: Design and rationale. Am Heart J 2016;182:28-35.

59. Ovbiagele B, Smith EE, Schwamm LH, Grau-Sepulveda MV, Saver JL, Bhatt DL, Hernandez AF, Peterson ED, Fonarow GC. Chronic kidney disease and 
bleeding complications after intravenous thrombolytic therapy for acute ischemic stroke. Circ Cardiovasc Qual Outcomes 2014;7:929-935.

60. Hsieh CY, Lin HJ, Sung SF, Yang YH, Lai EC, Hsieh HC, Chen CH. Does renal dysfunction modify the effect of intravenous thrombolysis for acute ischemic stroke within 4.5 hours of onset? A multicenter observational study. J Stroke Cerebrovasc Dis 2015;24:673-679.

61. Wein TH, Hickenbottom SL, Morgenstern LB, Demchuk AM, Grotta JC. Safety of tissue plasminogen activator for acute stroke in menstruating women. Stroke 2002;33:2506-2508.

62. Biswas S, Ajani AE. Interventionalists beware: the apical thrombus! Cardiovasc Revasc Med 2012;13:143.

63. Kasner SE, Villar-Cordova CE, Tong D, Grotta JC. Hemopericardium and cardiac tamponade after thrombolysis for acute ischemic stroke. Neurology 1998;50:1857-1859.

64. Stafford PJ, Strachan CJ, Vincent R, Chamberlain DA. Multiple microemboli after disintegration of clot during thrombolysis for acute myocardial infarction. BMJ 1989;299:1310-1312.

65. Derex L, Nighoghossian N, Perinetti M, Honnorat J, Trouillas P. Thrombolytic therapy in acute ischemic stroke patients with cardiac thrombus. Neurology 2001;57:2122-2125.

66. Yang CJ, Chen PC, Lin CS, Tsai CL, Tsai SH. Thrombolytic therapyassociated acute myocardial infarction in patients with acute ischemic stroke: A treatment dilemma. Am J Emerg Med 2017;35:804.

67. Kobayashi M, Tanaka R, Yamashiro K, Ueno Y, Kato E, Miura S, Daida H, Hattori N. Pre-existing Mobile Cardiac Thrombus and the Risk of Early Recurrent Embolism after Intravenous Thrombolysis: A Case Report. J Stroke Cerebrovasc Dis 2015;24:161-163.

68. Acampa M, Guideri F, Tassi R, D'Andrea P, Marotta G, Lo Giudice G, Martini G. Thrombolytic treatment of cardiac myxoma-induced ischemic stroke: a review. Curr Drug Saf 2014;9:83-88.

69. Mendes A, Mendonca T, Sousa A, Moreira G, Carvalho M. Stroke secondary to aortic dissection treated with a thrombolytic: a successful case. Neurol Sci 2012;33:107-110.

70. Noel M, Short J, Farooq MU. Thrombolytic therapy in a patient with acute ischemic stroke caused by aortic dissection. Clin Neurol Neurosurg 2010;112:695-696.

71. Graber JJ, Nayak L, Deangelis LM. Use of recombinant tissue plasminogen activator in cancer patients with acute stroke. J Neurooncol 2012;107:571-573.

72. Murthy SB, Karanth S, Shah S, Shastri A, Rao CP, Bershad EM, Suarez JI. Thrombolysis for acute ischemic stroke in patients with cancer: a population study. Stroke 2013;44:3573-3576.

73. Masrur S, Abdullah AR, Smith EE, Hidalgo R, El-Ghandour A, Rordorf G, Schwamm LH. Risk of thrombolytic therapy for acute ischemic stroke in patients with current malignancy. J Stroke Cerebrovasc Dis 2011;20:124-130.

74. Cappellari M, Carletti M, Micheletti N, Tomelleri G, Ajena D, Moretto G, Bovi P. Intravenous alteplase for acute ischemic stroke in patients with current malignant neoplasm. J Neurol Sci 2013;325:100-102.

75. Ingall TJ, O'Fallon WM, Asplund K, Goldfrank LR, Hertzberg VS, Louis TA, Christianson TJ. Findings from the reanalysis of the NINDS tissue plasminogen activator for acute ischemic stroke treatment trial. Stroke 2004;35:2418-2424.

76. Foell RB, Silver B, Merino JG, Wong EH, Demaerschalk BM, Poncha F, Tamayo A, Hachinski V. Effects of thrombolysis for acute stroke in patients with pre-existing disability. CMAJ 2003;169:193-197.

77. Savitz SI, Lew R, Bluhmki E, Hacke W, Fisher M. Shift analysis versus dichotomization of the modified Rankin scale outcome scores in the NINDS and ECASS-II trials. Stroke 2007;38:3205-3212.

78. Karlinski M, Kobayashi A, Czlonkowska A, Mikulik R, Vaclavik D, Brozman M, Svigelj V, Csiba L, Fekete K, Kõrv J, Demarin V, Vilionskis A, Jatuzis D, Krespi Y, Ahmed N, Wahlgren N; Safe Implementation of Treatments in Stroke-Eastern Europe (SITS-EAST) Investigators. Role of preexisting disability in patients treated with intravenous thrombolysis for ischemic stroke. Stroke 2014; 45:770-775.

79. Hong KS, Saver JL. Years of disability-adjusted life gained as a result of thrombolytic therapy for acute ischemic stroke. Stroke 2010;41:471-477.

80. Eriksson M, Jonsson F, Appelros P, Asberg KH, Norrving B, Stegmayr B, Terént A, Asplund K; Riks-Stroke Collaboration. Dissemination of thrombolysis for acute ischemic stroke across a nation: experiences from the Swedish stroke register, 2003 to 2008. Stroke 2010;41:1115-1122.

81. Hughes S. DAWN: Thrombectomy Effective Up to 24 Hours After Stroke. 2017. http://www.medscape.com/viewarticle/880144\#vp_1

82. Zinkstok SM, Engelter ST, Gensicke H, Lyrer PA, Ringleb PA, Artto V, Putaala J, Haapaniemi E, Tatlisumak T, Chen Y, Leys D, Sarikaya H, Michel P, Odier C, Berrouschot J, Arnold M, Heldner MR, Zini A, Fioravanti V, Padjen V, Beslac-Bumbasirevic L, Pezzini A, Roos YB, Nederkoorn PJ. Safety of thrombolysis in stroke mimics: results from a multicenter cohort study. Stroke 2013;44:1080-1084.

83. Hemmen TM, Meyer BC, McClean TL, Lyden PD. Identification of nonischemic stroke mimics among 411 code strokes at the University of California, San Diego, Stroke Center. J Stroke Cerebrovasc Dis 2008;17:23-25.

84. Scott PA, Silbergleit R. Misdiagnosis of stroke in tissue plasminogen activator-treated patients: characteristics and outcomes. Ann Emerg Med 2003;42:611-618.

85. Evans MRB, White P, Cowley P, Werring DJ. Revolution in acute ischaemic stroke care: a practical guide to mechanical thrombectomy. Pract Neurol 2017; 17:252-265

86. Peker A, Arsava EM, Topcuglu MA, Arat A. Akut İskemik İnme: Mekanik Trombektomi Cihazı Olarak "Stentriever" Kullanımı. Turkiye Klinikleri J Radiol-Special Topics 2017;10:86-92.

87. Bhatia R, Hill MD, Shobha N, Menon B, Bal S, Kochar P, Watson T, Goyal $M$, Demchuk AM. Low rates of acute recanalization with intravenous recombinant tissue plasminogen activator in ischemic stroke: real-world experience and a call for action. Stroke 2010;41:2254-2258.

88. Rudd T, Bowen A, James M, Young G. National clinical guideline for stroke Prepared by the Intercollegia the Stroke Working Party. 2016. https://www. strokeaudit.org/Guideline/Full-Guideline.aspx.

89. Demeestere J, Garcia-Esperon C, Lin L, Bivard A, Ang T, Smoll NR, Garnett A, Loudfoot A, Miteff F, Spratt N, Parsons M, Levi C. Validation of the National Institutes of Health Stroke Scale-8 to Detect Large Vessel Occlusion in Ischemic Stroke. J Stroke Cerebrovasc Dis 2017;26:1419-1426.

90. Pérez de la Ossa N, Carrera D, Gorchs M, Querol M, Millán M, Gomis M, Dorado L, López-Cancio E, Hernández-Pérez M, Chicharro V, Escalada X, Jiménez X, Dávalos A. Design and validation of a prehospital stroke scale to predict large arterial occlusion: the rapid arterial occlusion evaluation scale. Stroke 2014; $45: 87-91$.

91. Carrera D, Campbell BC, Cortés J, Gorchs M, Querol M, Jiménez X, Millán M, Dávalos A, Pérez de la Ossa N. Predictive Value of Modifications of the Prehospital Rapid Arterial Occlusion Evaluation Scale for Large Vessel Occlusion in Patients with Acute Stroke. J Stroke Cerebrovasc Dis 2017;26:74-77.

92. Heldner MR, Hsieh K, Broeg-Morvay A, Mordasini P, Bühlmann M, Jung S, Arnold M, Mattle HP, Gralla J, Fischer U. Clinical prediction of large vessel occlusion in anterior circulation stroke: mission impossible? J Neurol 2016;263:1633-1640.

93. Turc G, Maïer B, Naggara O, Seners P, Isabel C, Tisserand M, Raynouard I, Edjlali M, Calvet D, Baron JC, Mas JL, Oppenheim C. Clinical Scales Do Not Reliably Identify Acute Ischemic Stroke Patients With Large-Artery Occlusion. Stroke 2016;47:1466-1472.

94. Goyal M, Menon BK, van Zwam WH, Dippel DW, Mitchell PJ, Demchuk AM, Dávalos A, Majoie CB, van der Lugt A, de Miquel MA, Donnan GA, Roos YB, Bonafe A, Jahan R, Diener HC, van den Berg LA, Levy EI, Berkhemer OA, Pereira VM, Rempel J, Millán M, Davis SM, Roy D, Thornton J, Román LS, Ribó M, Beumer D, Stouch B, Brown S, Campbell BC, van Oostenbrugge RJ, Saver JL, Hill MD, Jovin TG; HERMES collaborators. Endovascular thrombectomy after large-vessel ischaemic stroke: a meta-analysis of individual patient data from five randomised trials. Lancet 2016;387:1723-1731.

95. Topcuoglu MA, Arsava EM. Stroke Treatment: Current News and Developments Turk J Neurol 2016;22:145-147.

96. Anderson CS, Robinson T, Lindley RI, Arima H, Lavados PM, Lee TH, Broderick JP, Chen X, Chen G, Sharma VK, Kim JS, Thang NH, Cao Y, Parsons MW, Levi C, Huang Y, Olavarría VV, Demchuk AM, Bath PM, Donnan GA, Martins S, Pontes-Neto OM, Silva F, Ricci S, Roffe C, Pandian J, Billot L, Woodward M, Li Q, Wang X, Wang J, Chalmers J; ENCHANTED Investigators and Coordinators. Low-Dose versus Standard-Dose Intravenous Alteplase in Acute Ischemic Stroke. N Engl J Med 2016;374:2313-2323. 